\title{
Fluvial history of the Rio Ilave valley, Peru, and its relationship to climate and human history
}

\author{
Catherine A. Rigsby ${ }^{\mathrm{a}, *}$, Paul A. Baker ${ }^{\mathrm{b}}$, Mark S. Aldenderfer ${ }^{\mathrm{c}}$ \\ a Department of Geology, East Carolina University, Greenville, NC 27858, USA \\ b Division of Earth and Ocean Sciences, Duke University, Durham, NC 27708, USA \\ c Department of Anthropology, University of California, Santa Barbara, CA 93106, USA
}

Accepted 17 January 2003

\begin{abstract}
Fluvial strata and landforms in the Rio Ilave valley (Peru) document a history of Holocene aggradation and downcutting that is correlative with regional climatic events and provides an environmental context for human occupation of the river valley. Periods of aggradation correspond to periods of high (or rising) level in Lake Titicaca and elsewhere on the Altiplano, and increased sediment accumulation in the Rio Ilave valley. Downcutting episodes correspond to periods of low level in Lake Titicaca and low or rapidly decreasing sedimentation rates in the Ilave delta. There are five terrace tracts (T1 through $\mathrm{T} 5$ ) present in this southwestern Lake Titicaca tributary. These tracts occur as both paired and unpaired terraces and have average heights from 1.4 to $24.3 \mathrm{~m}$ above the valley floor. The major part of the fluvial sequence was deposited during the time period from prior to the Last Glacial Maximum until about 8300 calendar years Before Present (cal BP) - a period of generally high (but variable) precipitation on the Altiplano and high water level in Lake Titicaca. Initial deposition (aggradation) was followed by successive downcutting to the T4 and T3 terrace surfaces. Initial downcutting began immediately after precipitation, runoff, and sediment load decreased while base level dropped. It was followed by a period of episodic equilibrium and minor downcutting that included a prolonged period of soil formation between $\sim 8350$ and $6780 \mathrm{cal}$ BP. The major pulses of downcutting likely occurred between $\sim 6000$ and 4500 cal BP and were coincident with periods of decreased precipitation on the Altiplano and decreasing levels of Lake Titicaca. Two final periods of infilling, resulting in deposition of the T2 and T1 terrace sediments at $\sim 4000$ to 2500 cal BP and $\sim 2000$ to 1600 cal BP (during periods of rising water level in Lake Titicaca, lacustrine sedimentation in the Rio Desaguadero valley, and increased sedimentation offshore the Ilave delta), were separated by brief equilibrium stages and a brief downcutting event. This fluvial history, when coupled with regional paleoclimatic data, relates to the region's preceramic through Tiwanakuperiod archeological records. Archeological evidence indicates that humans occupied the Ilave valley as early as 10000 cal BP. The higher terraces (T3, T4 and T5) were occupied for at least 5000 years, but humans did not utilize the lower terraces (T1 and T2) until after $\sim 4400-3700$ cal BP. Our results confirm that these lower terraces would not have been available for either occupation or agriculture until after $\sim 4000$ cal BP.
\end{abstract}

(C) 2003 Published by Elsevier Science B.V.

Keywords: Holocene; fluvial sedimentology; climate; archeology; Altiplano; Peru

\footnotetext{
* Corresponding author. E-mail addresses: rigsbyc@mail.ecu.edu (C.A. Rigsby), pbaker@duke.edu (P.A. Baker), m.aldenderfer@ucsb.edu (M.S. Aldenderfer).
} 


\section{Introduction}

Humans entered the Titicaca basin by 10000 cal BP (Aldenderfer and Klink, 1996; Aldenderfer, 1998a; Klink, in press) and by the eve of the Spanish conquest, the basin was the scene of one of the densest populations in the Andean world. Even though the close dependence of agropastoral return on the state of climate and the natural environment is a constant reality of the human occupation of the Altiplano, during the past and into the foreseeable future, the role of climatic variation in the cultural evolution of the Titicaca basin is poorly understood. For example, although it has been suggested that the collapse of Tiwanaku after AD 1000 was associated with long-term drought (Ortloff and Kolata, 1993; Binford et al., 1997), we know little about how climate affected certain critical processes in prehistory such as the domestication of indigenous plants and animals. How populations grew and thrived in a harsh and apparently unpredictable climate is a major research issue in the anthropological study of highland peoples in general and in the Titicaca basin in particular. How the landscapes occupied by those people changed in response to climate forcing and how these changes may have affected the human occupants of the landscape are the major foci of this paper.

Because riparian resources formed the basis for the subsistence economy of the early inhabitants of the basin, the fluvial history of watersheds is particularly important. It has been claimed that humans are the major modifiers of the landscape in the Lake Titicaca basin (e.g. Erickson, 1999, 2000), but in the Rio Ilave valley human alterations are small (agricultural enhancement of soil erosion, for example) in comparison to natural landscape evolution. In most of the watersheds of the Lake Titicaca basin (Fig. 1), landscape evolution is primarily controlled by fluvial processes. The fluvial data presented here allow us to begin to examine systematically the question of how Holocene climate variability affects the landscape and how landscape variability affects human activities. We are at an advantage in this region, relative to many traditional fluvial geomorphic studies, because we know the history of both climate and base level (the level of Lake Titicaca).

Middle Holocene precipitation on the Altiplano was perhaps $40 \%$ less than modern (Cross et al., 2001). This aridity caused the level of Lake Titicaca to drop as low as $85 \mathrm{~m}$ below its present level (Seltzer et al., 1998; Cross et al., 2000). The aridity was enduring, but punctuated by millennially paced wetter periods (Baker et al., 2001b). As summertime insolation increased throughout the southern tropics, Early Holocene aridity gave way to generally wetter conditions starting after 5000 cal BP. The Late Holocene, wet 'climatic optimum' of the Altiplano was also marked by millennially paced wetter periods (Baker et al., 2001b), the most recent of which coincided with the Little Ice Age of the northern high latitudes (Thompson et al., 1986).

Although it is generally agreed that climate is important in the evolution of fluvial systems (Porter et al., 1992; Brigdland, 2000, and many others), much controversy exists as to how much, and on what time-scales, it is important. While Vandenberghe (1995) suggests that climate is most significant on orbital time-scales, studies by Nanson et al. (1993) and Erskin and Warner (1988) caution against regarding short-term climate changes as minor in relation to orbital-scale changes. Most workers do agree that major changes in the fluvial environment occur during times of climatic transition (e.g. Knox, 1972; Rose and Boardman, 1983; Bull, 1991; Vandenberghe, 1995; Brigdland, 2000; Reneau, 2000). And, it has been suggested that the main climatic control on river systems is discharge variability (Schumm, 1993; Miall, 1996; Jones et al., 2001). In systems with minimal vegetation (and, typically, low sediment cohesion), such as the Ilave, increases in runoff lead to increases in sediment load, delivery of large amounts of sediment to either the local or the absolute base level, and to valley aggradation (e.g. Rose et al., 1980; Rose and Boardman, 1983; Bull, 1991; Sugai, 1993; Allen and Breshears, 1998).

Because the Rio Ilave drains the Cordillera Occidental - an active volcanic arc - a large portion of the source sediment is composed of easily eroded pyroclastic deposits. But, although Late 
Pleistocene glaciation in the Cordillera Occidental accelerated the supply of these pyroclastic sediments to fluvial systems and to Lake Titicaca (Baker et al., 2001b; Seltzer et al., 2002), active volcanism has played no other discernible role in Holocene fluvial evolution of the basin. The youngest macroscopic ash found in Lake Titicaca cores dates at 27000 cal yr BP (Baker et al., 2001b). Also, there was apparently no time in the Holocene when the vegetative cover in the basin was so great that sediment cohesion would have been dramatically altered (Paduano et al., this issue). The relative unimportance of these complicating factors simplifies the task of trying to deduce the most important relationships among the histories of precipitation, base level (Lake Titicaca level), and fluvial aggradation vs. incision in the Ilave valley.

\section{Geomorphic and climatic setting}

Lake Titicaca (Fig. 1), at an elevation of $3810 \mathrm{~m}$, is the highest large lake in the world and the largest lake of South America. The lake occupies an endorheic basin that extends from about $14^{\circ}$ to $17^{\circ} \mathrm{S}$ and from about $68^{\circ}$ to $71^{\circ} \mathrm{W}$. This basin, the northern part of the Bolivian and Peruvian Altiplano, is bordered by the Cordillera Occidental to the west, the Cordillera Oriental to the east, and the Cordillera Vilcanota to the north. The southern limit of the basin is lower, and the lake overflows periodically (depending on lake level) into the Rio Desaguadero that discharges into the large, shallow, saline Lago Poopo, and the presently dry salars (salt flats) of Coipasa and Uyuni. The Rio Ilave is one of the five major tributaries to Lake Titicaca; in order of decreasing discharge these tributaries are the Ramis, Ilave, Coata, Huancane, and Suchez.

The northern Altiplano has a cold, semi-arid climate. Average annual precipitation in the Lake Titicaca watershed is about $800 \mathrm{~mm}$. Precipitation is strongly seasonal with approximately $3 / 4$ of the annual precipitation falling in a four-month period from December through March. The annual cycle of precipitation on the Altiplano is highly correlated with the annual cycle of deep

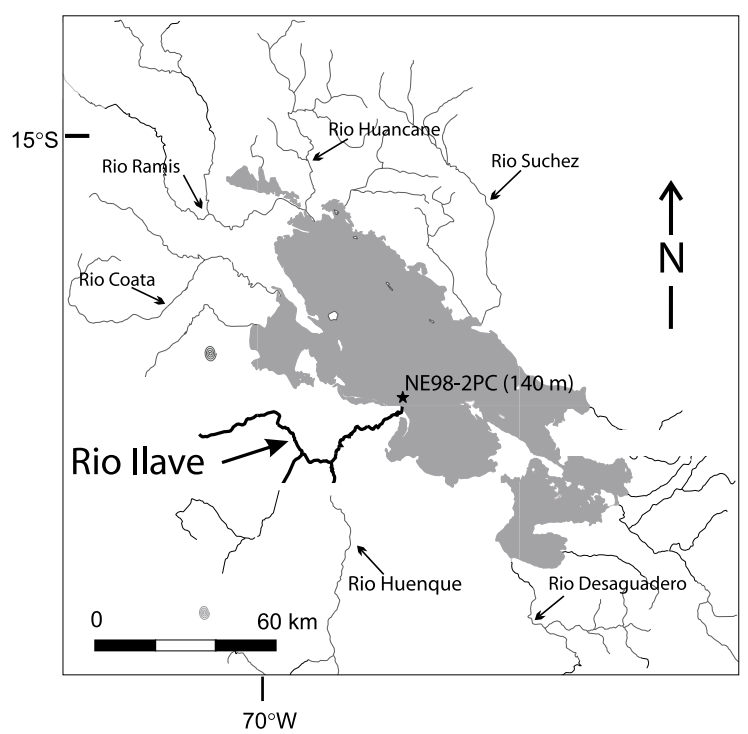

Fig. 1. Map of the Lake Titicaca basin showing the Rio Ilave and other major drainages.

convection that develops over most of tropical South America during the austral summer (Aceituno and Montecinos, 1993; Aceituno, 1996). The Pacific coastal temperature inversion, aided by the relatively steep lapse rate and the Andean orographic barrier, precludes significant moisture flux from this source (Garreaud, 1999). Modern instrumental records illustrate the rapid response of fluvial discharge in the Titicaca basin to the summer season precipitation peak, and the rapid response of lake level (base level) to summer discharge peaks (Fig. 2). Changes in lake level are clearly related to seasonal as well as interannual precipitation variability.

Intraseasonal to interannual precipitation variability on the Altiplano is attributable to a number of different atmospheric circulation patterns (Lenters and Cook, 1997, 1999). Because the position and intensity of the Bolivian high control flow throughout much of the height of the troposphere from the Andean crest upward, they also control the advection of moisture onto the Altiplano from the Amazon basin. Aceituno and Montecitos (1993) demonstrated that the Bolivian high is shifted southward, and easterly moisture flux is enhanced, during wet intraseasonal events on the Altiplano. Modern statistical (Vuille et al., 


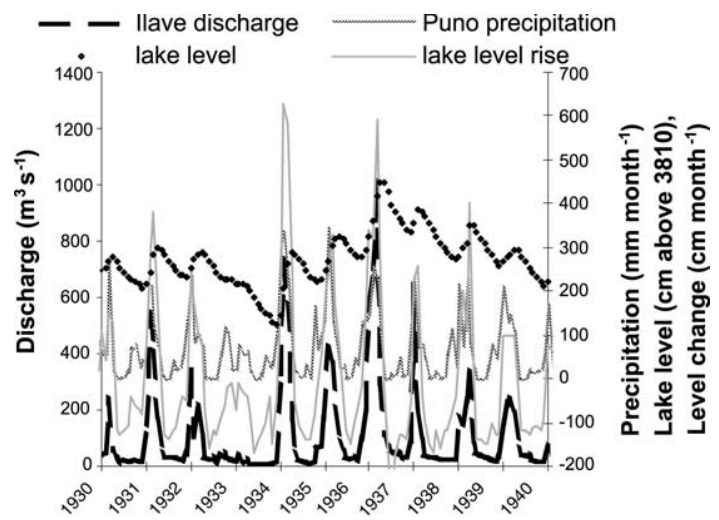

Fig. 2. The level of Lake Titicaca has been recorded at Puno, Peru, since 1914. The highly seasonal nature of the rainfall on the Altiplano causes increased input to the lake (as illustrated by the Ilave discharge) and a sharp lake level rise near the end of the wet season. This rise is followed by a slower, evaporation-driven, fall of lake level spread over the remainder of the year and, at high lake stages, discharge via the Rio Desaguadero.

2000) and synoptic (e.g. Lenters and Cook 1999; Garreaud and Aceituno, 2001; Garreaud et al., this issue) climatological studies have repeatedly demonstrated the importance of similar controls on interannual precipitation variability in the central Andes that are well correlated with El Niño Southern Oscillation (ENSO) variability. This ENSO-related interannual precipitation variability clearly affects riverine discharge and lake level (Fig. 2); it also influences modern agricultural yields on the Altiplano (Orlove et al., 2000).

There has been little study of the nature and origin of precipitation variability on the Altiplano on decadal to millennial time-scales, yet such variability must play an important role in the fluvial and landscape processes. Two archives of climate information that are relevant to this issue are the Quelccaya ice core (Thompson et al., 1986) and the lake level history of Lake Titicaca, measured at Puno, Peru, since 1914 (Servicio Nacional de Meterologia y Hydrologia del Peru). The annual rise of water level in Lake Titicaca is well correlated with the wet season (and annual) precipitation amount on the northern Altiplano (Fig. 3). Moreover, Melice and Roucou (1998) showed that $\delta^{18} \mathrm{O}_{\text {ice }}$ from the Quelccaya ice cap (Thompson et al., 1986) is inversely correlated with annu-

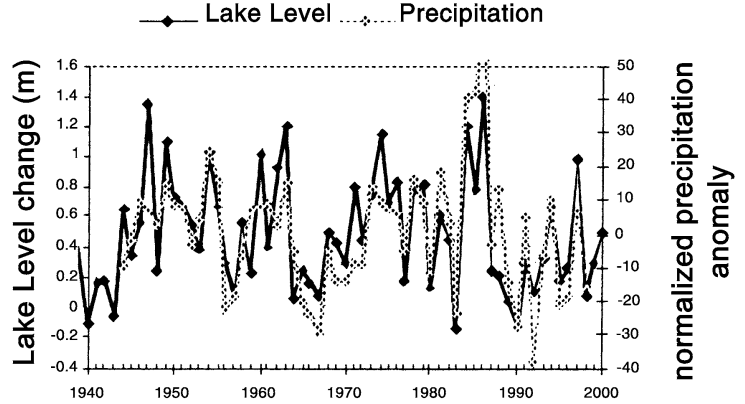

Fig. 3. Annual rise of lake level (October-April) is correlated with the instrumental record of annual precipitation within the northern Altiplano (normalized rainfall departures from 20 stations in the Lake Titicaca watershed): lake level rise is a good measure of precipitation integrated throughout the basin. ENSO and quasi-decadal fluctuations of lake level are evident.

al lake level rise in Lake Titicaca, hence the ice core isotopic composition can itself be used as a proxy for regional precipitation (Fig. 4). Melice and Roucou (1998) also demonstrated in the Quelccaya record that there is a statistically significant, large amplitude, persistent variance with a period of about 13 years. We believe that this apparent quasi-decadal variability of precipitation on the northern Altiplano is related to the quasidecadal variability of northern equatorial Atlantic

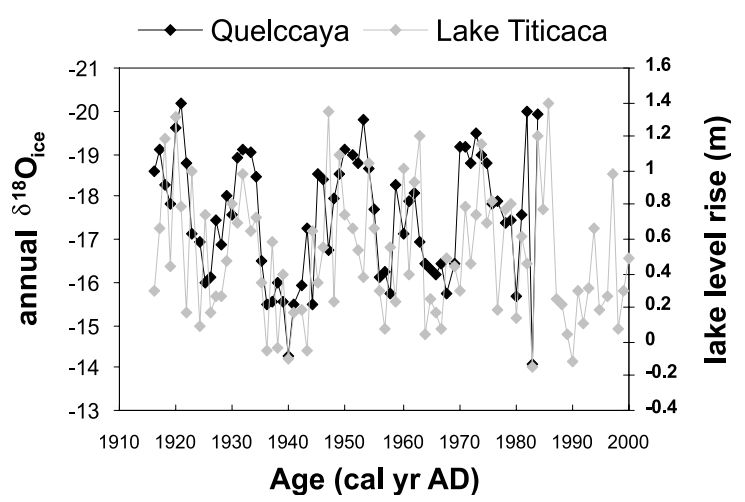

Fig. 4. There is a significant correlation between the $\delta^{18} \mathrm{O}_{\text {ice }}$ from Quelccaya and annual lake level rise $\left(r^{2}=0.2424\right.$, $n=69$, significant at the $99 \%$ confidence level), a less significant correlation between layer thickness at Quelccaya and lake level rise $\left(r^{2}=0.1558, n=69\right)$, and no significant correlation between $\delta^{18} \mathrm{O}_{\text {ice }}$ and layer thickness for the period 1500 $1984\left(r^{2}=0.0125, n=485\right)$. Thus, $\delta^{18} \mathrm{O}_{\text {ice }}$ is an excellent proxy for past precipitation; ice layer thickness is not. 
sea surface temperature (Fig. 5; see also Nobre and Shukla, 1996, their fig. 14)

Millennial-scale precipitation variability on the Altiplano is documented throughout the Holocene by the Sajama ice core (Thompson et al., 1998; Fig. 6) and Lake Titicaca sediment cores (Baker et al., 2001b). Baker et al. (2001b) proposed that these millennial events are linked in time, and perhaps by forcing mechanism, to the 'Bond events' of the North Atlantic (Bond et al., 1997; DeMenocal et al., 2000; Bond et al., 2001).

Insolation control by the precessional cycle has a major impact on the intensity of the South American Summer Monsoon (SASM; Zhou and Lau, 1998) and on the summertime precipitation amount on the Altiplano. The last two maxima of summertime insolation over tropical South America were at $\sim 21000$ cal yr BP and at present (Berger and Loutre, 1991). Response to this orbital variability is evident in sediments from Lake Titicaca and the Salar de Uyuni. Lake Titicaca was very fresh and overflowing at $21000 \mathrm{cal} \mathrm{yr}$ $\mathrm{BP}$ and is fresh and (barely) overflowing today, but in the Early and Middle Holocene, the lake level fell to $85 \mathrm{~m}$ below its outlet (Seltzer et al., 1998). In the Salar de Uyuni the insolation maxima are coincident with thick accumulations of lacustrine muds. However, the presence of lakes during periods of low insolation (e.g. $30000 \mathrm{yr}$ BP; Baker et al., 2001a), coincident with Heinrich events and cold temperatures in the North Atlan-

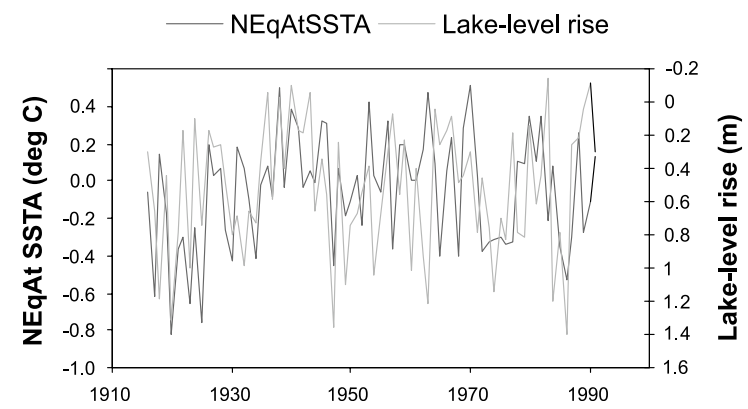

Fig. 5. Time series of annual rise of level of Lake Titicaca compared with the time series of DJFM Sea Surface Temperature (SST) anomaly for the northern equatorial Atlantic $\left(7.5^{\circ}\right.$ to $22.5^{\circ} \mathrm{N}, 2.5^{\circ} \mathrm{E}$ to $37.5^{\circ} \mathrm{W}$; SST anomaly data from Kaplan et al., 1997). Colder SSTs in the northern equatorial Atlantic correlate with wet conditions in much of Amazonia (Nobre and Shukla, 1996) and in the northern Altiplano.

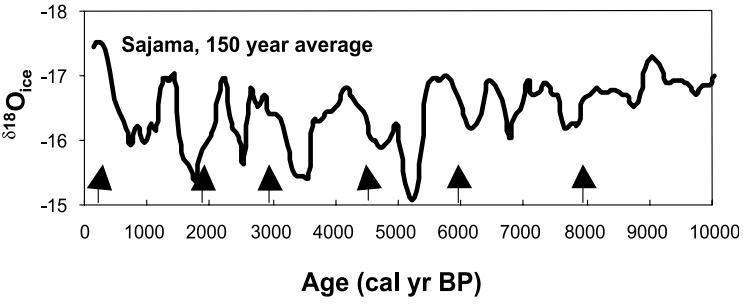

Fig. 6. $\delta^{18} \mathrm{O}_{\text {ice }}$ in the Sajama ice cap (Thompson et al., 1998), three-point moving average of presumed 50-yr intervals. Millennial events of $1-1.5 \%$ amplitude are persistent throughout the Holocene. The arrows highlight the millennial cold SST events deduced from sediment cores offshore West Africa (DeMenocal et al., 2000) and synchronous with the 'Bond events' of the subpolar North Atlantic (Bond et al., 2001). Baker et al. (2001b) hypothesized that tropical Atlantic meridional SST gradients force millennial wet-dry cycles in the Lake Titicaca watershed.

tic, suggests that the pattern of cold North Atlantic/wet Altiplano observed in the Holocene record also is found in earlier portions of the record.

Tributaries to Lake Titicaca must respond to these quasi-decadal, multi-decadal, millennial, and orbital variations in precipitation, recording their responses in the sediments of the terraced river valleys. In the Rio Ilave valley, sediments preserved in terraces and modern cutbanks document a history of aggradation and downcutting that we attribute to regional Holocene climate change. Specifically, as the data reported here show, periods of aggradation are correlative with periods of increased precipitation (and rapid rise of Lake Titicaca) and periods of downcutting are correlative with periods of decreased precipitation (and falls or standstills of Lake Titicaca).

\section{Methods}

Our analysis of terraced, Holocene-age fluvial sequences in the Rio Ilave valley and our interpretations of their climatic causes and possible human responses are based on archeological and climatological data sets and on detailed examination of the geomorphic and sedimentologic character of the river basin. Terrace and modern cutbank exposures were mapped and measured using standard techniques for sedimentological facies analysis (such as those outlined by Miall, 1996; 
Reading, 1996). Emphasis was placed on identification and description of lateral and vertical facies changes (facies architecture) utilizing variations in grain size, sedimentary structures, bed morphology, and contacts. Sediments comprising the terraces were described in detail, key elevations and a longitudinal profile surveyed, terraces profiles constructed (with the aid of a total station and Global Positioning System (GPS) equipment), and datable organic material sampled.

Well-preserved, datable organic material is scarce in these strata. Where present it consists of small amounts of disseminated organic detritus (woody material and charcoal) within the slightly sandy mud lithofacies. These samples were subjected to radiocarbon analysis at the National Ocean Sciences Accelerated Mass Spectrometer Facility, Woods Hole Oceanographic Institute. The CU-Boulder INSTAAR Laboratory for AMS Radiocarbon Preparation and Research performed all the preparations. CALIB 4.3 (Stuiver and Braziunas, 1993; Stuiver et al., 1998a,b) was used to convert the radiocarbon ages to calibrated years Before Present (cal BP). Discussion in the text focuses on the $2 \sigma$ calibrated ages; both calibrated and uncalibrated ages for all samples used in this study are presented in Table 1.
These sedimentologic techniques allow us to differentiate among the major fluvial depositional environments preserved in the terrace sediments, to identify smaller-scale environments (such as channel, point bar, crevasse splay, wetland, and floodplain) in some locations, and to use these distinctions to make interpretations about the impact of Holocene precipitation variability on the fluvial processes in the Ilave valley. We broaden the context of these environmental changes by comparing the fluvial data with archeological data from survey and excavation projects in the Ilave and Huenque drainages (Aldenderfer and Klink, 1996; Klink and Aldenderfer, 1996; Aldenderfer and de la Vega, 1997; Klink, in press) and with climate and lake level (base level) data from Lake Titicaca (Baker et al., 2001b).

\section{Terrace sediments}

Sediments that comprise the Rio Ilave terraces are fluvial silts, sands, and gravels that occur in three distinct facies associations (FAs): gravelly braided river deposits, sandy braided river deposits, and meandering river deposits. Braided river deposits are more abundant than meandering river deposits, occurring throughout the upper and

Table 1

Sample numbers, location names, terrace numbers, and radiocarbon and calibrated ages for all the samples used in this study

\begin{tabular}{llllcc}
\hline Sample number & Laboratory number & Location name & Terrace number & $\begin{array}{l}\text { Radiocarbon age } \\
(\mathrm{yr} \text { BP })\end{array}$ & $\begin{array}{l}\text { Calibrated age } \\
(\mathrm{yr} \text { BP })\end{array}$ \\
\hline HS-2 & CURL-5464 & Quinafaja & T1 & $1660 \pm 35$ & $1673 \pm 39$ \\
HS-1 & CURL-5462 & Quinafaja & T2 & $2560 \pm 40$ & $2577 \pm 93$ \\
HS-3 & CURL-5465 & Quinafaja & T2 & $3440 \pm 50$ & $3702 \pm 129$ \\
RC1-b & CURL-5457 & Rio Uncallane & T2 & $2540 \pm 187$ & - \\
CH-3 & CURL-5460 & Chingani & T3 & $33000 \pm 27$ & - \\
HS2-1 & CURL-5461 & Quinafaja & T3 & $29000 \pm 180$ & - \\
QP2-1 & CURL-5466 & Quebrada Pucara & T3 & $21700 \pm 200$ & $13040 \pm 70$ \\
QP2-2 & CURL-5467 & Quebrada Pucara & T3 & $26980 \pm 170$ & - \\
QP2-3 & CURL-5468 & Quebrada Pucara & T3 & $8345 \pm 63$ & $8837 \pm 206$ \\
Toto 2 & CURL-5456 & Totorani & T4 & $8832 \pm 201$ & $8020 \pm 75$ \\
Toto 3 & CURL-5455 & Totorani & T4 & $5980 \pm 40$ & $6808 \pm 86$ \\
Toto 5 & OS-27588 & Totorani & T4 & $5930 \pm 40$ & $6735 \pm 70$ \\
Toto 5 & OS-27587 & Totorani & T4 & $6080 \pm 45$ & $6938 \pm 54$ \\
Toto 5a & OS-27590 & Totorani & T4 & $5980 \pm 45$ & $6813 \pm 96$ \\
Toto 5a & OS-27589 & Totorani & T4 & $7400 \pm 45$ & $8262 \pm 94$ \\
Toto 6 & OS-27591 & Totorani & T4 & & \\
\hline
\end{tabular}


Table 2

Summary of lithofacies used in this study

\begin{tabular}{|c|c|c|c|}
\hline $\begin{array}{l}\text { Facies } \\
\text { code }\end{array}$ & Description & Sedimentary structures & Interpretation \\
\hline $\mathrm{Gm}$ & Gravel, matrix-supported & Horizontal bedding, common imbrication & Channel fill; bar \\
\hline Gmsh & Gravel clast-supported & Horizontal bedding, commonly imbrications & Channel fill; bar \\
\hline Gp & $\begin{array}{l}\text { Gravel, transitional between clast and } \\
\text { matrix supported }\end{array}$ & Planar cross-bedding & Channel fill; bar \\
\hline Gt & Gravel, clast-supported & Trough cross-bedding & Channel fill; bar \\
\hline Sh & Sand, very fine to very coarse & Horizontal bedding & Channel fill; bar \\
\hline $\mathrm{Sp}$ & Sand, fine to coarse, locally pebbly & Planar cross-bedding & Channel fill; bar \\
\hline Spw & Sand, medium to silty sand & $\begin{array}{l}\text { Planar, wavy, ripple, to climbing ripple } \\
\text { laminations }\end{array}$ & Point bar; levee \\
\hline Smg & $\begin{array}{l}\text { Sand, fine to very coarse, locally } \\
\text { dispersed pebbles and mud rip-ups }\end{array}$ & Massive & Channel fill; bar \\
\hline St & $\begin{array}{l}\text { Sand medium to very coarse, locally } \\
\text { pebbly }\end{array}$ & Trough cross-bedding & Channel fill; bar \\
\hline $\mathrm{Fm}$ & Mud & Massive & Channel fill; bar \\
\hline Fml & Mud & Massive or planar laminations & $\begin{array}{l}\text { Overbank and/or floodplain; } \\
\text { inactive channel }\end{array}$ \\
\hline Fprw & Silt, mud, clay; common clay drapes & $\begin{array}{l}\text { Planar, wavy, ripple, or climbing ripple } \\
\text { laminations; convolute bedding }\end{array}$ & $\begin{array}{l}\text { Levee and/or crevasse splay; } \\
\text { overbank and/or floodplain }\end{array}$ \\
\hline Fsm & Silt & Massive or planar laminations & $\begin{array}{l}\text { Overbank and/or floodplain; } \\
\text { inactive channel }\end{array}$ \\
\hline
\end{tabular}

central reaches of the river valley. Meandering river deposits are confined to the lower reaches of the river valley, in the areas downstream of Totorani (Fig. 7). The lithofacies that constitute these FAs (Table 2) were classified on the basis of grain size, sedimentary structures, biological components, and stratigraphic position, following the procedures of Miall (1996, 1982) and Rust (1978). The lateral and vertical distribution of lithofacies, along with groupings of their characteristics, formed the basis for the FA definitions (Table $3)$. Descriptions of the FAs and their characteristic lithofacies, as well as interpretations of the depositional environments, are presented below and illustrated in Figs. 8 and 9.

\subsection{Gravelly braided river deposits (FA-1)}

Gravelly braided river deposits occur only in the terraces of the Rio Uncallane tributary and the lowest (oldest) strata in terraces along the central stretch of the Ilave (between the Rio Uncallane and the Rio Huenque; Fig. 7). This FA, which includes the coarsest grained strata present in the Rio Ilave terraces, is characterized by crudely bedded, fining- and coarsening-upward se-

Table 3

Description, dominant lithofacies, and depositional environment of the FAs preserved in terrace exposures of the Rio Ilave

\begin{tabular}{llll}
\hline $\begin{array}{l}\text { Facies as- } \\
\text { sociation }\end{array}$ & $\begin{array}{l}\text { Dominant or } \\
\text { characteristic lithofacies }\end{array}$ & Description & $\begin{array}{l}\text { Depositional } \\
\text { environment }\end{array}$ \\
\hline FA-1 & Gm, Gt, Gp, Smg, Sp, & $\begin{array}{l}\text { Crudely bedded, fining- and coarsening-upward sequences of cross- } \\
\text { bedded and laminated gravels with minor sand and mud }\end{array}$ & $\begin{array}{l}\text { Gravelly braided } \\
\text { stream deposits }\end{array}$ \\
& Fm & $\begin{array}{l}\text { Gnsm, Gm, Smg, St, Sh, } \\
\text { Complexly cross-bedded, fining-upward sequences of coarse sand with }\end{array}$ & $\begin{array}{l}\text { Sandy braided } \\
\text { stream deposits } \\
\text { local gravel and minor mud }\end{array}$ \\
FA-3 & $\begin{array}{l}\text { Fp, Spw, Fsm, Fml Fprw, Fsm, Spw, } \\
\text { Fmg }\end{array}$ & $\begin{array}{l}\text { Planar laminated to cross-laminated to massive muds, silts, and sands } \\
\text { in thick fining-upward sequences }\end{array}$ & $\begin{array}{l}\text { Meandering stream } \\
\text { deposits }\end{array}$ \\
\hline
\end{tabular}



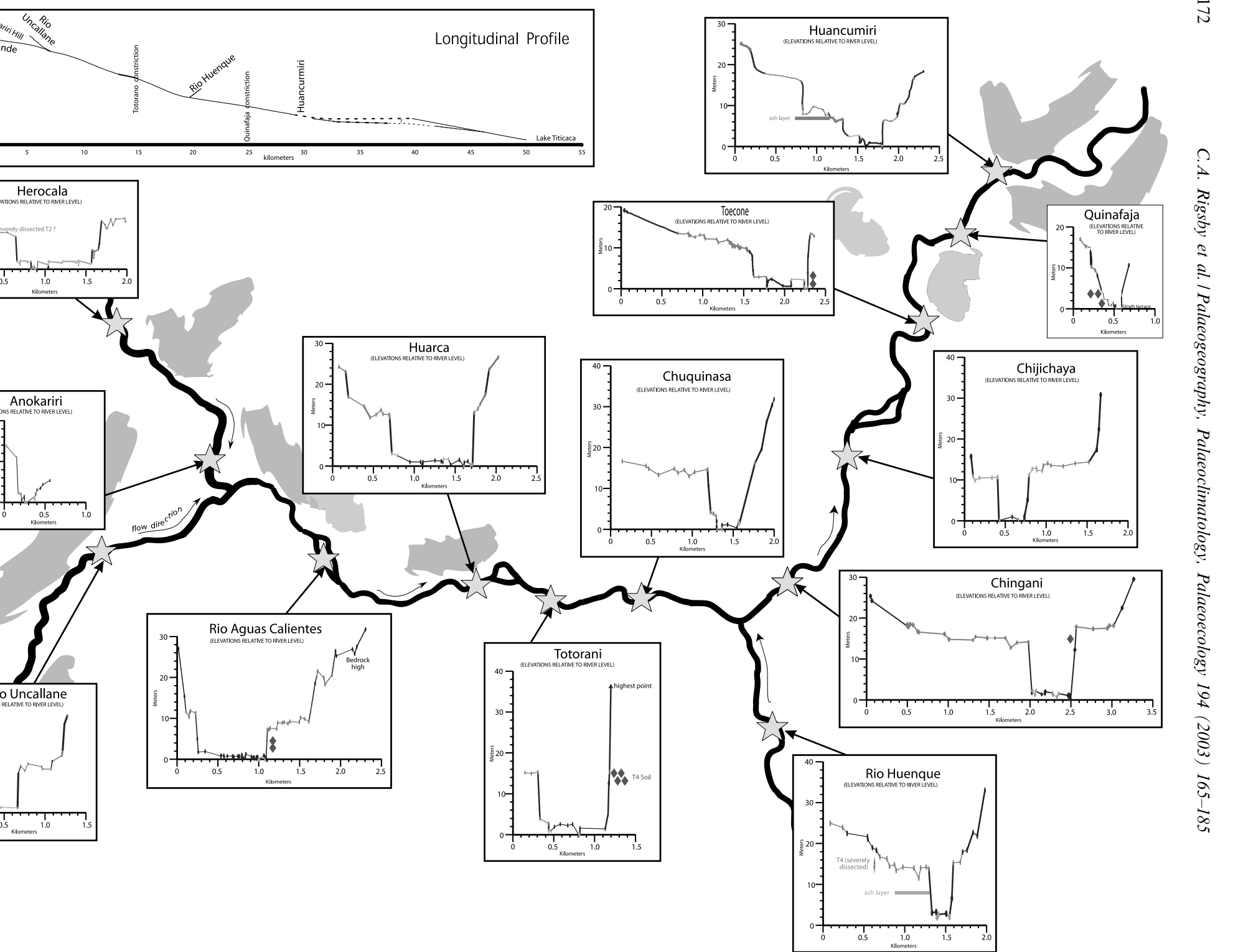

Fig. 7. Rio Ilave terrace profiles and longitudinal profile. Diamonds mark locations of key dates; shaded areas show bedrock highs. 
quences of gravel, with minor amounts of sand and mud (Fig. 8A).

\subsubsection{Description of lithofacies}

Fine-grained lithofacies are rare in FA-1. The only fine-grained lithofacies present in FA-1, lithofacies Fm (massive mud), occurs as rare, thin $(>0.25 \mathrm{~m})$ beds interspersed between the thick sand and gravel lithofacies. Sandy lithofacies in FA-1 include planar cross-bedded, medium to very coarse sand $(\mathrm{Sp})$ and massive pebbly sand (Smg).

Three coarse-grained lithofacies dominate FA1: lithofacies $\mathrm{Gm}, \mathrm{Gt}$, and $\mathrm{Gp}$. Lithofacies $\mathrm{Gm}$ is horizontally bedded, clast-supported, and locally imbricated coarse gravel and gravelly sand. Clast size ranges from pebble to boulder, with cobblesize clasts dominant. Lithofacies Gt and Gp consist of trough and planar cross-bedded gravel, respectively. Lithofacies Gt is a clast-supported cobble to boulder conglomerate. Lithofacies $\mathrm{Gp}$ is transitional from clast- to matrix-supported and generally finer grained (containing mainly cobbleand pebble-size clasts) with varying amounts of sand-size matrix material. These gravel lithofacies occur as $1-1.5-\mathrm{m}$-thick stacked gravel beds or as 0.5-2.5-m-thick, sharp-based units that fine upward and are capped by thin $(>0.3 \mathrm{~m})$ beds of lithofacies Smg or Sp.

\subsubsection{Interpretation}

A gravelly braided river, similar to the braided stretches of the modern Rios Ilave and Uncallane, deposited FA-1. Evidence supporting this interpretation includes the abundance of coarsegrained sediment, the presence of complexly interbedded coarse-grained sediments, the interbedded fining- and coarsening-upward sequences, and the scarcity of fine-grained lithofacies. This FA preserves complexly intercalated bar and channel sequences such as those present in the proximaland mid-reaches of modern gravelly braided rivers (Reineck and Singh, 1980; Miall, 1978).

Braiding results from large and rapid fluctuations in river discharge, abundance of coarse sediments, high rates of sediment supply, and easily eroded banks (Shelton and Noble, 1974; Cant and Walker, 1978; Cant, 1982). Under such con- ditions, the stream channel is rapidly choked with coarse bedload. Rapid decreases in velocity cause instantaneous deposition, consequently sediments are poorly sorted and the most common lithofacies are channel gravels and low relief bar deposits (Gm, Gp, Gt, and Sp). Such deposits dominate both periglacial and non-glacially influenced braided systems (Smith, 1974; Boothroyd and Ashley, 1975; Rust, 1978; Smith and Smith, 1984).

\subsection{Sandy braided river deposits (FA-2)}

Sandy braided river deposits of FA-2 are common in the central reaches of the Rio Ilave valley, especially in the Rio Aguas Calientes and Totorani reaches (Figs. 7 and 8B). Stacked, complexly cross-stratified, fining-upward, lapillaceous sands and gravelly sands with thin interbeds of silt and mud characterize these strata. FA-2 is distinguished from FA-1 by an overall lack of gravel, the dominance of sandy distinct, fining-upward sequences, and the common occurrence of interbedded muds.

\subsubsection{Description of lithofacies}

Sandy lithofacies dominate FA-2. Lithofacies Smg (massive gravelly sand), St (trough crossbedded coarse to gravelly sand), $\mathrm{Sp}$ (planar cross-bedded very coarse to medium sand), and Sh (horizontally stratified coarse to fine sand) occur in 0.5-3-m-thick, fining-upward sequences. Lithofacies St is the most abundant sandy lithofacies in the FA. The sandy sequences are locally interbedded with thin $(0.2-0.8 \mathrm{~m})$ beds of parallel to ripple-laminated silt and silty sand ( $\mathrm{Spw}$ and Fsm) and massive to laminated silt and mud (Fm and Fml). Gravel lithofacies are rare in these strata. Lithofacies Gmsh and Gm occur locally at the base of sandy fining-upward units, but thick gravel beds are not present. Individual gravelly and cross-bedded sand beds of this FA can be traced laterally throughout much of the central portion of the study area.

\subsubsection{Interpretation}

FA-2 was deposited by a sandy braided river. Fining-upward sequences are common in sandy 


\begin{tabular}{|c|c|c|}
\hline \multicolumn{3}{|c|}{ Explanation of symbols } \\
\hline 00 & Gravelly lithofacies & Silty lithofacies \\
\hline 3 & Sandy lithofacies & Fine-grained lithofacies \\
\hline $1\{5-5 x$ & Root mottling & के \& $\&$ Gastropods \\
\hline leitir & $\begin{array}{l}\text { Disseminated } \\
\text { organics }\end{array}$ & (n) \\
\hline : 80 & $\begin{array}{l}\text { Dispersed } \\
\text { pebbles }\end{array}$ & \\
\hline$\approx$ & $\begin{array}{l}\text { Wavey bedding } \\
\text { Rip-up clasts }\end{array}$ & Trough crossbedding \\
\hline
\end{tabular}

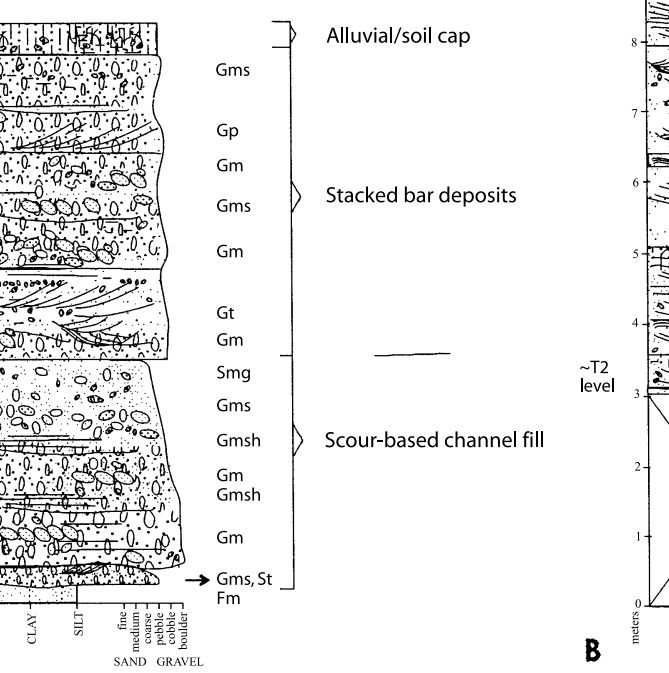

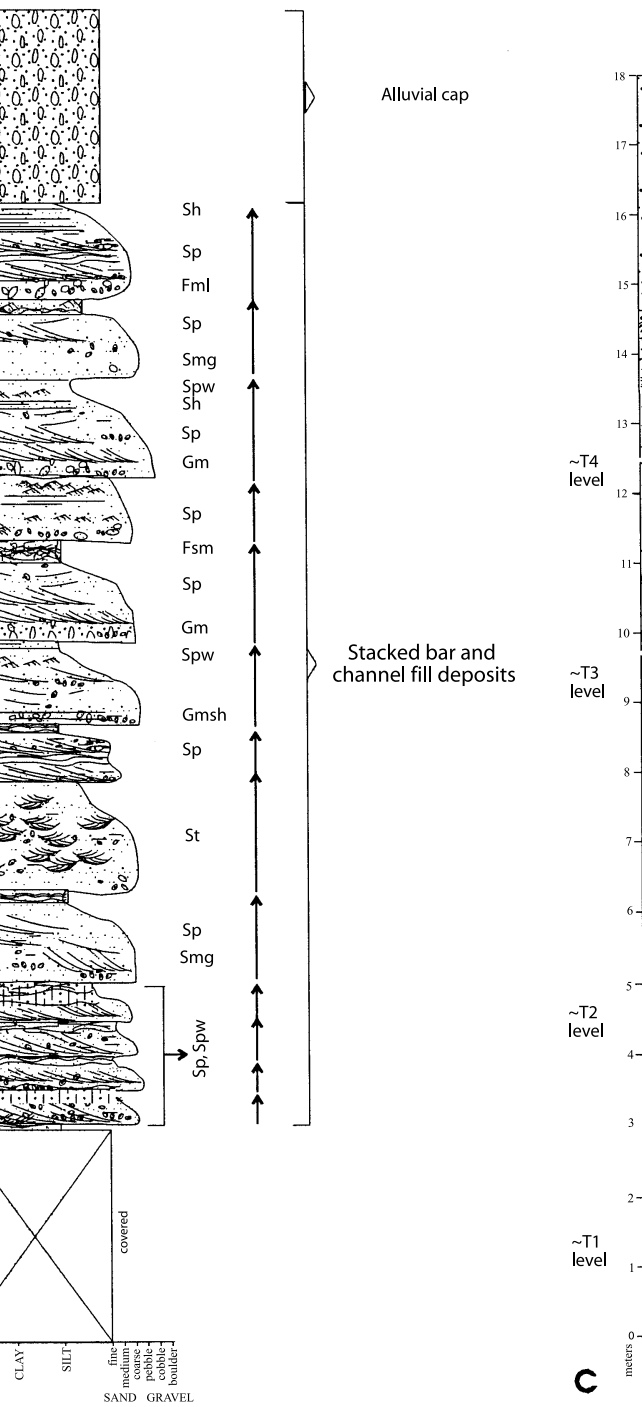

Fig. 8. Typical measured stratigraphic sections from the Rio Ilave terrace exposures. (A) Gravelly braided river strata; composite section from the Rio Uncallane. (B) Sandy braided river strata; composite section from the Totorani area. (C) Meandering river strata; composite section from the Huancumiri-Quinafaja area. Arrows show direction of fining. See Fig. 10 for locations and Table 2 for lithofacies descriptions. 
braided systems. Fining-upward sequences such as the ones preserved in this FA generally result from sedimentation in braided channels (Miall, 1982; Reineck and Singh, 1980). They also result from waning flow over bars and channels as the result of accretion during active channel migration (Davis, 1983). Such sequences suggest cycles of fluctuating energy regimes. They may record individual flood cycles (Darby et al., 1990) and are probably related to annual to millennial-scale fluctuations of precipitation. Individual coarse units (Gm, Gmsh, Smg) are channel deposits (Miall, 1982). Pebble stringers and channelized gravels more likely represent lags on scour surfaces (Reading, 1996).

\subsection{Meandering river deposits (FA-3)}

Meandering river strata (FA-3) are abundant in the Rio Ilave terraces. They are present in all of the terrace exposures downstream of Huarca (Fig. 7). This FA is characterized by $0.5-6.0-\mathrm{m}$-thick sedimentary packages dominated by distinct fining-upward sequences of volcanigenic sands and tuffaceous siltstones and mudstones, thick sequences of interbedded silt and mud, and local lenses of sandy gravel, silt, and mud (Fig. 8C). FA-3 occurs both above and laterally adjacent to (grading from) FA-2. It is distinguished from FA-1 and FA-2 by a lack of gravel and the presence of thick sequences of silt and mud.

\subsubsection{Description of lithofacies}

The lithofacies that comprise FA-3 are Fml, Fprw, Fsm, Spw, and Smg. The sandy lithofacies occur at the bases of fining-upward sequences. Lithofacies Smg, a massive sand with locally dispersed pebbles and mud rip-up clasts, commonly exhibits an erosive base and typically grades upward into planar- to wavy- to cross-laminated silty sand (Spw). Lithofacies Fsm consists of massive to laminated silt and silty clay in beds ranging from a few centimeters to $0.5 \mathrm{~m}$ in thickness. It occurs as individual fining-upward sequences and as interbeds within finer grained strata. Lithofacies Fml, massive to planar-laminated mud, occurs within fining-upward sequences, typically overlying lithofacies Spw. Lithofacies Fprw is characterized as a planar- to wavy-laminated silt to silty clay to clay, with common mud drapes and soft-sediment deformation features. It occurs locally atop fining-upward sequences and, in the Huancumiri section (Figs. 7 and 8C), as a thick sequence of thinly bedded and complexly laminated, rippled, and climbing rippled very fine sand, silt, and mud.

\subsubsection{Interpretation}

FA-3 records deposition in a meandering river. This FA is dominated by thick (approximately 0.4 to $>5 \mathrm{~m}$ ) overbank or floodplain deposits (lithofacies Fsm, Fml, Fmp, Fpwr) that rest above fining-upward channel and point bar deposits (Smg, Spw, Fsm). Evidence for the meandering river interpretation includes the absence of interbedded channel and bar lithofacies, the overall finegrained nature of the strata, and the presence of thick overbank deposits and fining-upward sequences. Similar fining-upward meandering river strata have been documented in Holocene terrace (Baucom and Rigsby, 1999) and subsurface (Rollins et al., 2000; Rollins, 2001) strata of the Rio Desaguadero valley, where they are interpreted to coincide with periods of increased effective moisture on the Altiplano.

\section{Fluvial history}

The meandering and braided river strata of the Rio Ilave valley are exposed in five distinct terrace tracts. The terrace morphology, age, sedimentary characteristics, and history of formation are, as discussed in the following sections, intimately related to the regional climatic (precipitation) variations.

\subsection{Terrace morphology and age}

The five terrace tracts in the Ilave valley (T1T5) occur as both paired and unpaired terrace sets and have average heights from $1.4 \mathrm{~m}$ to $24.3 \mathrm{~m}$ above the modern river valley (Fig. 7). The complete suite of terraces is not present in all localities, but each terrace is identifiable by its sedimentary characteristics and its height above the 

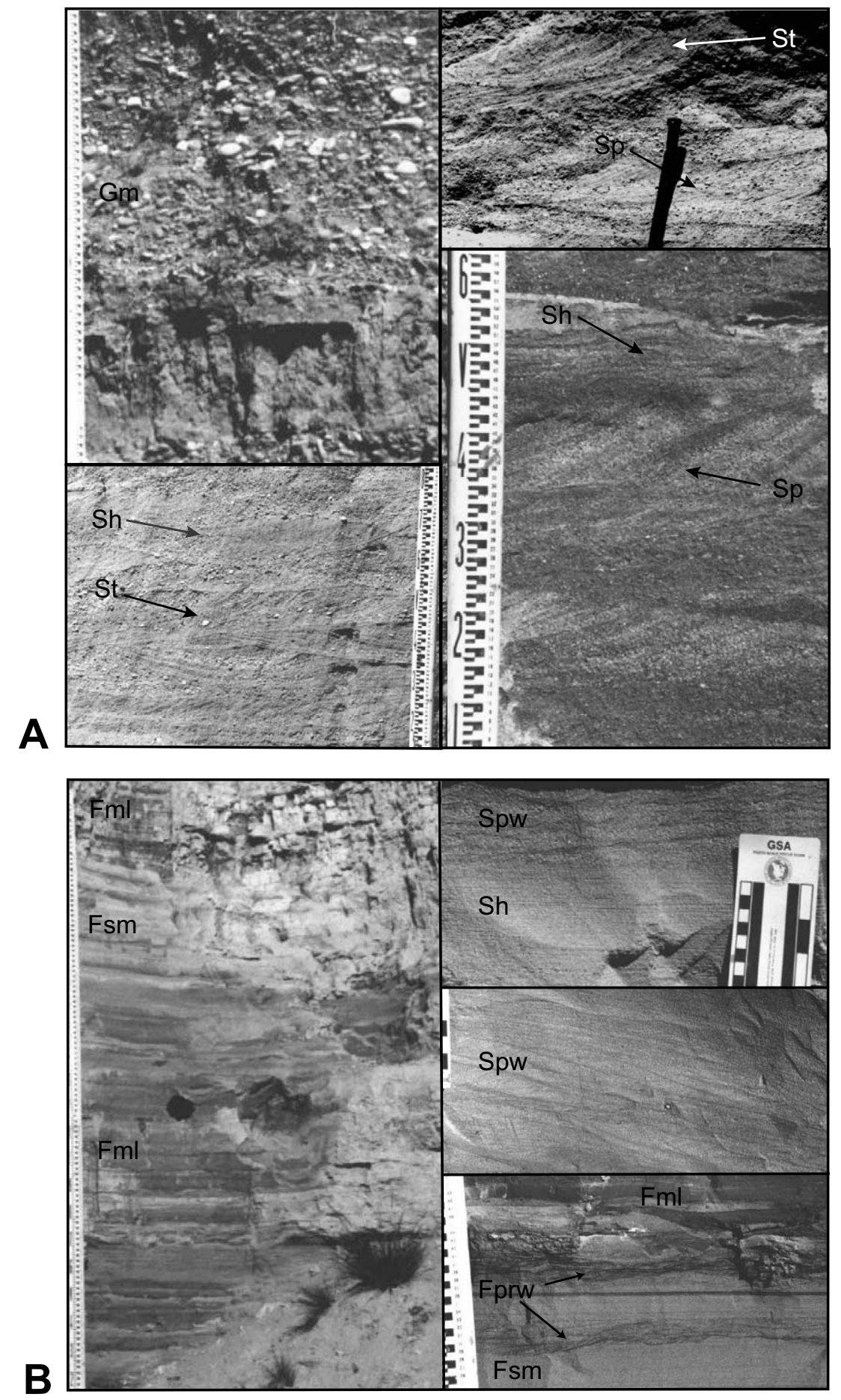
modern river (Fig. 10). In general, the terraces are best formed in the downstream reaches of embayments. At confluences terrace surfaces are well formed in both the downstream and upstream reaches. The upper four terraces occur, locally, as paired terraces. An unpaired strath terrace is present at the lowest terrace level near Quinafaja, but paired strath terraces do not occur. Only the two lowest terraces (T1 and T2) are demonstrably fill terraces; the others are cut-fill terraces (following the terminology of Bull, 1991). All of the terrace surfaces are actively cultivated by modern farmers and have cultivated zones up to $1 \mathrm{~m}$ deep.

The highest terraces (T3, T4, and $\mathrm{T} 5$ ) are present throughout most of the study area. They are composed of ash-rich fluvial strata (dominantly lapillaceous gravels and sands, tuffaceous siltstones, and mudstones). T5, the highest terrace surface at $24.3 \mathrm{~m}$ above river level, is highly dissected and is present from the Rio Uncallane downstream. It is most prevalent near the Rio Uncallane tributary, present locally downstream of Huarca, and absent in the upstream-most reaches - where the river is marshy and has low relief (see Figs. 7 and 10).

Terrace T4, with an average height of $15.7 \mathrm{~m}$, is the most persistent surface in the river valley and is present in all but the upstream-most, low-gradient, wetland-like sections. In the central part of the Ilave valley, the T4 level is identifiable as either a distinct terrace or as a gravelly sand horizon within the non-dissected stratigraphic section (Fig. 8). Where the T4 terrace surface is well formed, the surface is capped by either a thick (up to $2 \mathrm{~m}$ ) soil horizon or a gravel cap. Gravels dissect the T4 surface to a depth that reaches $3.5 \mathrm{~m}$ above the modern river (more than $3 / 4$ of the $\sim 15 \mathrm{~m}$ terrace height) in the downstream reaches of the Totorani embayment. Terrace T3 is present in both upstream and downstream reaches, but absent in the central portion of the river valley (between Rio Aguas Calientes and Chijichaya). Similar to the T4 terrace, T3 is comprised of ash-rich fluvial sediments, is not fully formed (cut) in the upstream reaches (embayments) above bedrock constrictions, but is well formed (cut) in the downstream reaches. Thin gravel caps $(<2 \mathrm{~m})$ are present locally. These highest terraces are generally lens-shaped; they are lowest immediately downstream of bedrock constrictions, highest and broadest in embayments. Samples of organic material from a thick soil horizon near the top of the T4 terrace yielded dates ranging from $8292 \pm 34 \mathrm{cal} \mathrm{BP}$ at the base of the soil to $6735 \pm 70 \mathrm{cal} \mathrm{BP}$ at the top. Samples from T3 sediments (from beneath the level of the T3 surface and stratigraphically lower than the T4 strata) range in age from $15420 \pm 735 \mathrm{cal} B P$ to $\sim 33000$ BP (Table 1). These samples suggest (but do not prove) that approximately $25 \mathrm{~m}$ of sediment (most of the T3 through T5 stratigraphic section) was deposited in the Ilave valley since the Late Glacial Maximum (LGM). Almost half of that strata was deposited, and subsequently downcut, during the Holocene.

The lowest terraces ( $\mathrm{T} 1$ and $\mathrm{T} 2$ ) are only present in the upstream and downstream reaches of the valley, adjacent to bedrock constrictions and in areas of relatively low relief (Figs. 7 and 10). Terrace $T 2$ has an average height of $4.83 \mathrm{~m}$ and is present only near the Quinafaja bedrock constriction and, possibly, at Herocala (Figs. 7 and 10). Terrace T1, the youngest surface above the modern channel, is the modern floodplain terrace. It is characterized by $1-1.5-\mathrm{m}$-high, distinct, narrow platforms on the inside of modern meanders. Organic material from the T2 and T1 sediments yielded dates of $3702 \pm 127$ to $2486 \pm 62 \mathrm{cal}$ $\mathrm{BP}$ and $1673 \pm 39$ cal BP, respectively (Table 1).

Fig. 9. Lithofacies characteristic of the three FAs present in the Rio Ilave terrace exposures. (A) Sandy and gravelly lithofacies typical of braided stream deposits. Massive gravel $(\mathrm{Gm})$, pebbly trough- and planar cross-bedded very coarse pebbly sand (St, $\mathrm{Sp}$ ), and horizonally laminated sand (Sh) are common in FA-1 (gravelly braided stream deposits). Interbeds of horizontally laminated and trough and planar cross-bedded medium to very coarse (locally pebbly) sand are common in FA-2 (sandy braided stream deposits). (B) Thick, fining-upward sequences of finer grained strata, such as ripple- and climbing ripple-laminated fine sand and mud (Spw and Fprw), massive to planar laminated silt (Fsm), laminated mud (Fml) and horizontally laminated fine to medium sand (Sh) are common in FA-3 (meandering stream deposits). 


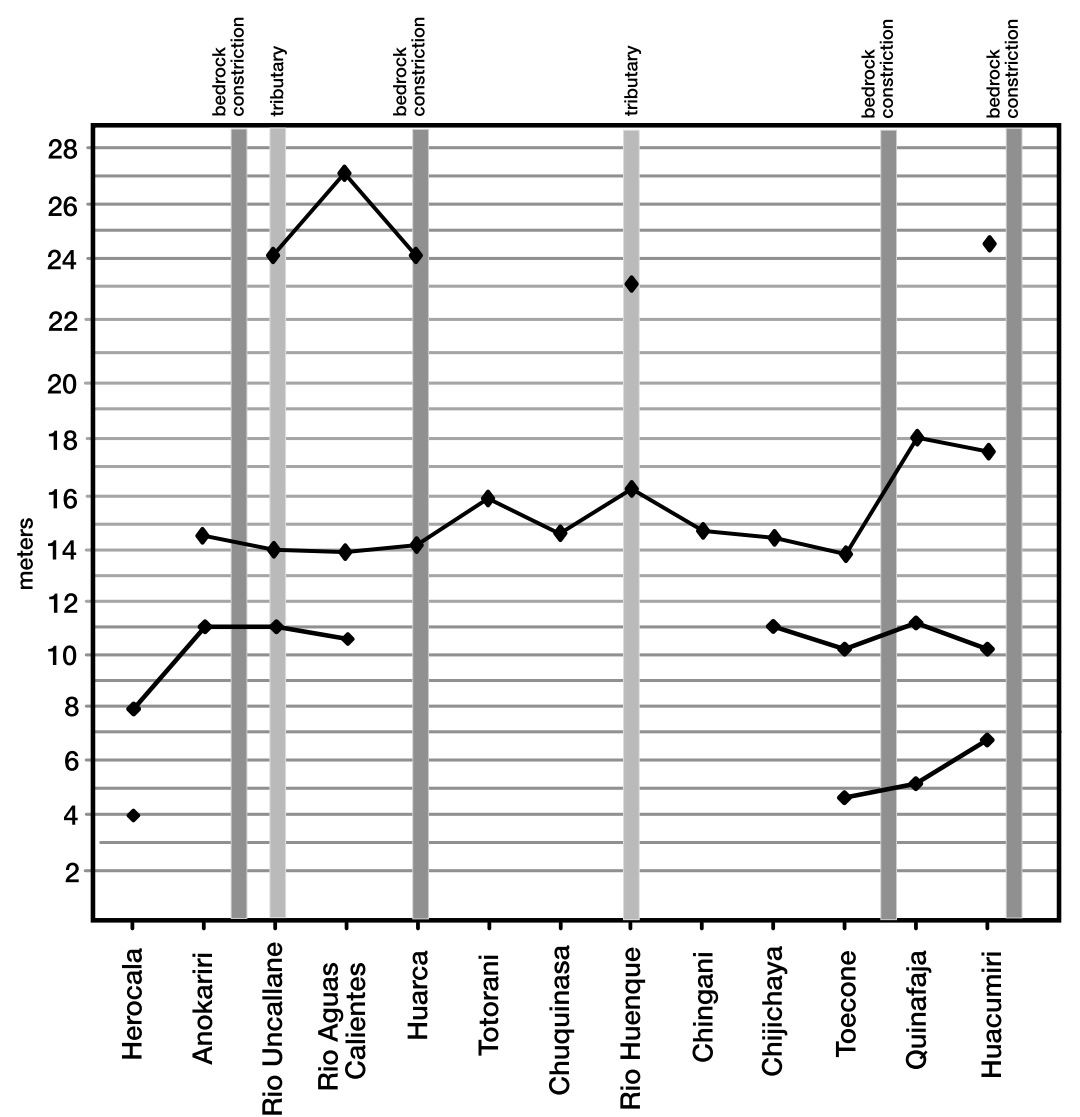

Fig. 10. Graph showing the heights of the four upper Rio Ilave terrace tracts. Terrace height is partially controlled by proximity to bedrock constrictions and tributaries.

\subsection{History of terrace development}

The sedimentologic and geomorphic characteristics of these terraces, along with the radiocarbon ages from terraces $\mathrm{T} 1$ through $\mathrm{T} 4$, allow us to develop a history of terrace development for the river valley (Fig. 11). Gullies that dissect the terrace suite near Quinafaja and Huacumiri expose a complex 3-D geometry. The sediments underlying terraces T3 through T5 are vertically continuous through the three-terrace sequences and grade down-gradient from gravelly braided stream deposits (FA-1) to sandy braided deposits (FA-2) to meandering stream (FA-3) deposits. No evidence of major erosional events or of long-term hiatuses is present in the composite 3-terrace stratigraphy (Fig. 8). This suggests that the sediments beneath these terraces were deposited in a contin- uous or nearly continuous manner. Aggradation of such thick sequences of fluvial strata is common in arid, rocky basins when large amounts of sandy sediment are introduced (Bull, 1991). If stream power is insufficient to handle the increased sediment load, the entire river valley may be choked with thick piles of sediment. Many river systems grade downstream from coarse-grained to fine-grained braided systems and, eventually, to meandering systems. The gradual downstream gradation of the sediments underlying the Rio Ilave terraces from gravelly braided river strata to meandering river strata is likely the result of a progressive downstream decrease in sediment load. This suggests that different reaches of the river valley filled at different rates depending on, for example, the length and gradient of the embayment and the availability 
and grain size of the source material. The occurrence of braided fluvial strata (FA-1 and FA-2) in the more upstream reaches - but at the same stratigraphic level as meandering strata in downstream reaches - is a result of the presence of bedrock constrictions behind which large volumes of sediment could be trapped, the differing gradients of individual embayments, and the downstream-decreasing availability of coarse-grained source material.

The T4 and T3 surfaces represent equilibrium stages during a progressive downcutting of these sediments. The complex distribution and heights of the T5 through T3 terraces are consistent with the overall basin geometry of alternating embayments and constrictions. As is typical of arid-region mountain streams (Bull, 1991), the Ilave valley terrace heights typically decrease upstream toward constrictions and the terrace widths are generally broader in embayments.

In contrast to the compound T3-T5 terrace set, terraces $\mathrm{T} 1$ and $\mathrm{T} 2$ are individual, inset, fill terraces. The T2 strata onlap the $\mathrm{T} 3$ terrace and the $\mathrm{T} 1$ strata onlap the T2 terrace (Fig. 11), indicating that these terraces were formed during two distinct episodes of aggradation.

\subsection{Terrace development and climate change}

A first step toward understanding the effects of these aggradational and downcutting phases on riparian biota and on the human occupants of the Ilave valley is to correlate the terrace history with the moderate-resolution records of climate and base level that are presently available (Baker et al., 2001b). Our correlation of the Ilave valley aggradational and degradational history with regional climatic events is illustrated in Fig. 12. The majority of the fluvial sequence (aggradation of the compound $\mathrm{T} 3-\mathrm{T} 5$ terraces) corresponds to a time of high precipitation on the Altiplano and rising or high water level in Lake Titicaca. The maximum age of this aggradation episode is not known, but the oldest reliable dates suggest that it started during the LGM wet period, was ongoing through the Younger Dryas wet period, and may have continued until $\sim 8250$ cal BP. High fluvioglacial runoff during this time resulted in increased sediment load and high sediment accumulation rates offshore from the Ilave delta (as recorded in sediments from core NE98-PC2; Figs. 1 and 12). With the input of large volumes of easily eroded volcanic-rich sediment from source areas in the Cordillera Occidental, contemporaneous with high base level (Lake Titicaca), sediment load was sufficient to fill the valley and choke the river system. In embayments behind bedrock constrictions, sediments were deposited to heights in excess of $25 \mathrm{~m}$ above the valley floor (compound terraces T3-T5). This aggradation was followed by the downcutting of the T4 and T3 terrace tracts. As documented in other settings (Bull, 1991), the shift from aggradation to downcutting was likely very rapid.

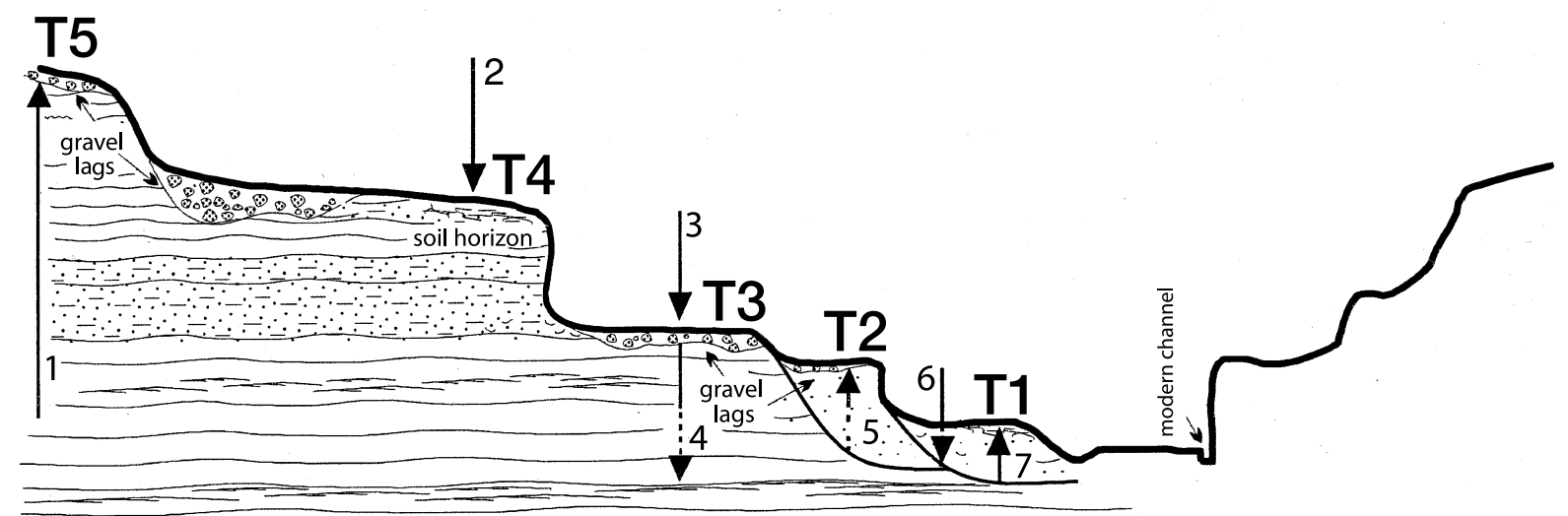

Fig. 11. Model for the aggradation and downcutting of the Rio Ilave terraces. Numbered arrows show sequence and directionality (aggradation or downcutting) of events. 


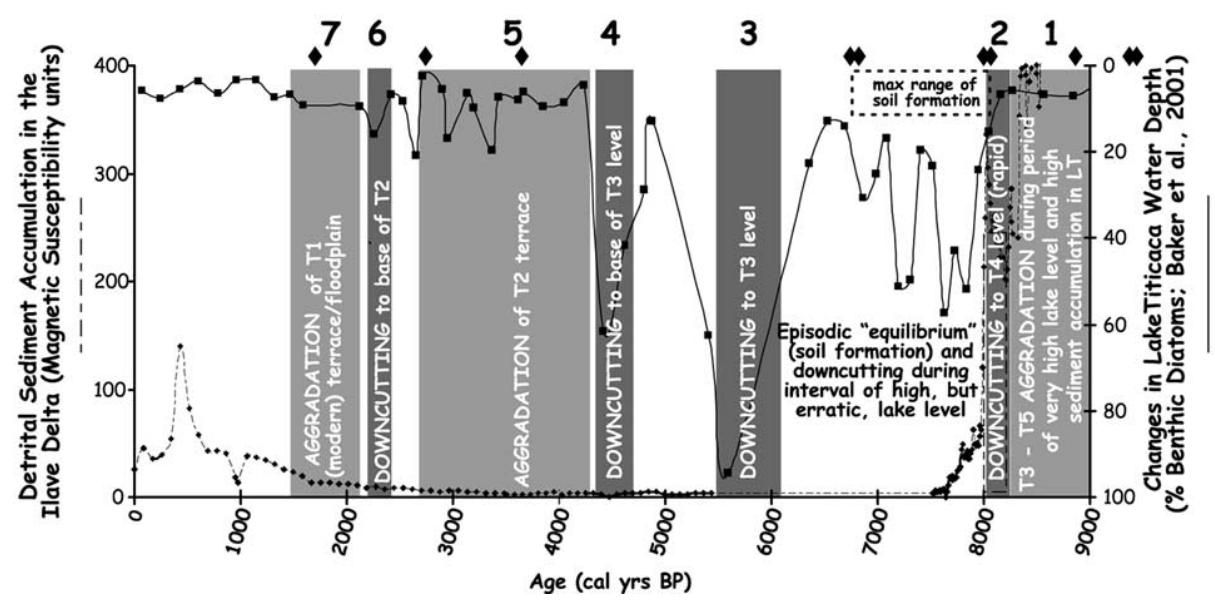

Fig. 12. Relationship between the Rio Ilave terrace development and changes in base level and sediment load. The benthic diatom record from a deep-water core (NE98-2PC) in Lake Titicaca is used as a proxy for lake level (solid line). The magnetic susceptibility log from a core taken at the toe of the Ilave delta records detrital sediment accumulation at base level (dashed line). The diamonds indicate radiocarbon dates in the fluvial sequence and the numbers correspond to the aggradational and downcutting events illustrated in Fig. 11. Note that periods of aggradation correspond to periods of high (or rising) lake level in Lake Titicaca (Abbott et al., 1997; Baker et al., 2001a) and (for all but T2) the periods of increased sediment accumulation in the Ilave delta. Further, each hypothesized aggradation period corresponds to a lacustrine period in the Rio Desaguadero valley (Baucom and Rigsby, 1999; Rollins, 2001). Downcutting episodes, which leave behind no datable strata, are bracketed in age by dates within the aggradational sequences and apparently correspond to periods of low lake level in Lake Titicaca (Baker et al., 2001a), low or rapidly decreasing sedimentation rates in the Ilave delta, and fluvial activity in the Rio Desaguadero valley (Baucom and Rigsby, 1999; Rollins, 2001).

The initial downcutting probably began immediately after precipitation, runoff, and sediment load decreased (as seen in the Ilave delta sediment accumulation record; Fig. 12), and base level dropped - probably just prior to $\sim 8000$ cal BP. Although the initial downcutting was likely very rapid, the terraced strata document several periods of episodic equilibrium. The longest equilibrium phase was the prolonged period of T4 terrace erosion and soil formation (between $\sim 8250$ and $6780 \mathrm{cal} \mathrm{BP}$ ). The T4 equilibrium phase was followed by the T3 downcutting episode. Downcutting to the base of T3 may have been episodic. It occurred between $\sim 6000$ and 4500 cal BP - the major downcutting episodes were likely coincident with periods of rapidly decreasing levels of Lake Titicaca (Fig. 12) and decreased precipitation on the Altiplano. The thickness of the gravel caps on these terraces and the thick soil at the top of the T4 terrace suggest that T4 had a longer equilibrium period than T3. Downcutting was followed by two periods of infilling that resulted in deposition of the $\mathrm{T} 2$ and $\mathrm{T} 1$ terrace sediments. The $\mathrm{T} 2$ and
T1 aggradational events occurred from $\sim 4000$ to 2500 cal BP and from $\sim 2200$ to 1600 cal BP, respectively - during millennial periods of rising water levels in Lake Titicaca, lacustrine sedimentation in the Rio Desaguadero valley (Baucom and Rigsby, 1999; Rollins, 2001) and the Salar de Uyuni (Baker et al., 2001a), and increased sedimentation off the Ilave delta. They were separated by brief equilibrium stages and brief downcutting events.

\section{Discussion}

The role that climatic variation has played in the social and political evolution of the peoples of the Titicaca basin as well as the peoples across the Andes, has been hotly debated for more than 30 years. Erickson $(1999,2000)$, for example, argues that many explanations of cultural change and process in the Andes are dominated by what he calls neo-environmental determinism. He is specifically critical of the suggestion that the collapse of 
Tiwanaku was directly caused by a long-term drought (Kolata and Ortloff, 1996; Ortloff and Kolata, 1993; Binford et al., 1997). While some of his interpretations of the existing paleoenvironmental record are inaccurate, his point is clear: over-reliance on gross characterizations of external forces, such as climatic variation, relegates humans to a strictly passive role. Explanations based on such forces fail to capture the creativity of humans during potentially difficult periods of environmental change.

Archeological survey data argue strongly for a human presence in the Titicaca basin by 10000 cal BP. Small numbers of lower-elevation peoples from the western Andean valleys began to use the Titicaca basin during the Early Archaic (Aldenderfer and Klink, 1996; Aldenderfer, 1998a; $\mathrm{K}$ link, in press). During most of the earliest human occupation (10000-8500 BP), Lake Titicaca was freshening and the lake was at a highstand from 9500 to $8500 \mathrm{cal}$ BP (Baker et al., 2001b). Although Poaceae (grasses) and Polylepis (queñua) were probably present around the lake margin (Paduano et al., this issue) - suggesting the establishment of habitat for camelids and taruca - data from the Ilave drainage and from the nearby Juli-Pomata region suggest that the near-lakemargin environments were not used extensively during this period (Stanish et al., 1997; Klink and Aldenderfer, 1996; Aldenderfer and Klink, 1996). Instead, the interior drainages were used extensively. Residential bases were established in the mountain valleys along the Altiplano rim, while the main portions of the river valleys were likely explored and utilized through day-use and longer-distance logistical forays.

Humans occupied the higher terraces of the Ilave (T3, T4, and T5) for at least 5000 years (prior to $\sim 4400$ cal BP) (Aldenderfer and Klink, 1996). Excavations at Jiskairumoko (at the T5 level in the central Ilave valley) show that a sedentary settlement is in place at the site in the Terminal Archaic (by $\sim 4200$ cal BP). Populations in the Ilave drainage increased significantly from the Terminal Archaic ( $4500-3500$ cal BP) to the Early Formative (3500-3000 cal BP); the lower Ilave terraces ( $\mathrm{T} 1$ and $\mathrm{T} 2)$ were not used extensively until after $\sim 4400-3700$ cal BP (Fig.
13), a trend also seen in data from the Rio Huenque (Klink, in press). This increase in population was coincident with a period of increased precipitation, rising levels of Lake Titicaca, and increased discharge and the formation of low terraces (T2) in the Ilave valley (Fig. 12).

The period 3500-2600 cal BP witnessed the expansion of small, apparently agropastoral, communities across much of the Titicaca basin (Aldenderfer, 1998b; Stanish, 2003). The existing settlement record in the basin suggests that the near-lake environments became more important through time. This is presumably correlated with the intensified reliance upon agricultural production in the economy and the freshening of the lake between 3500 and 3200 cal BP, a scenario described by Binford et al. (1997). However, according to the data from Lake Titicaca (Baker et al., 2001b), this expansion took place in three distinct paleoclimatic regimes. Interestingly, the broad shifts in climate during this time appear to parallel changes in both Ilave terrace morphology and agricultural technology in the southern basin. In

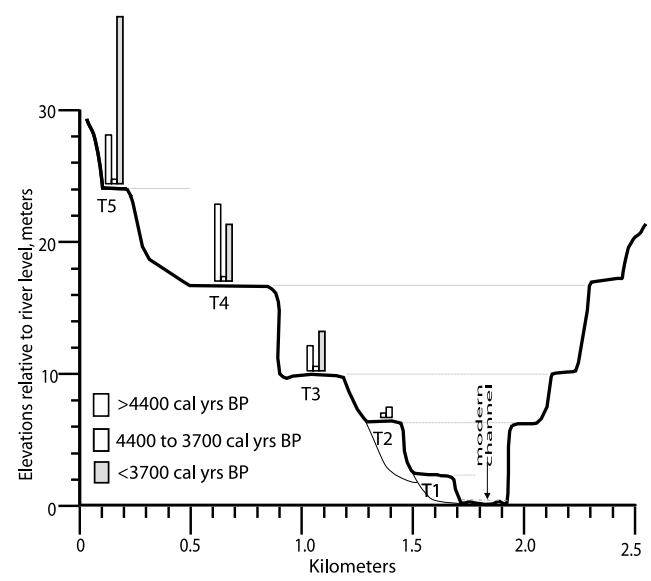

Fig. 13. Typical profile across the Rio Ilave valley showing the five distinct terraces discussed in the text. The superimposed population-density histograms, based on survey and excavation data (Aldenderfer and Klink, 1996; Klink and Aldenderfer, in press), illustrate the human/land-use relationships. Although some sites could have been lost during downcutting events (events 2, 3, 4, and 6 on Figs. 11 and 12), the overall relationship between human land-use and the fluvial landscape is clear: humans occupied the upper terraces (T3-T5) during the Early Archaic (prior to 4400 BP) and the low terraces (T2 and T1) were not used until the Terminal Archaic (4400-3700). 
the Ilave, Juli-Pomata, and Huenque survey areas, as well as in excavations at Camata (Steadman, 1995), andesitic hoes (rare prior to $3200 \mathrm{cal}$ BP) become increasingly common after $3200 \mathrm{cal}$ BP. Households may have used hoe technology as they moved into new settlement niches where soils were harder to manipulate with previous (presumably wooden tool) techniques (Boserup, 1965; Stanish, 2003). This implies a movement into the pampas surrounding river terraces and the lake margin. It may have been a response to drier conditions and the downcutting of previously available T2 terrace expanses. The downcutting of the $\mathrm{T} 2$ terrace (Figs. 11 and 12) was associated with a brief (post $\sim 3000 \mathrm{BP}$ ) period of variable, but decreased, lake level. After $\sim 2000$ cal BP, lake levels returned to, or slightly above (Abbott et al., 1997; Baucom and Rigsby, 1999), modern levels, precipitation increased, and the $\mathrm{T} 1$ terrace was formed, once again providing fresh fluvial landscapes for agricultural use.

\section{Summary}

Instrumental records show that, on seasonal to decadal time-scales, changes in the Rio Ilave discharge are related to changes in precipitation as well as changes in the level of Lake Titicaca. Our investigation of the Rio Ilave terraces suggests that the Ilave River also responded to centennialand millennial-scale events - especially changes in precipitation and consequent changes in sediment load. According to paleoclimatic reconstructions and our history of terrace development, the Ilave valley was relatively wet during the initial human occupation. This was a time of high, but erratic, lake levels and of soil formation on the high terraces of the river valley. Humans occupied the higher terraces (T3, T4, and T5) for at least 5000 years $(\sim 10000$ to sometime prior to $\sim 4400$ cal BP). The lower terraces (T1 and T2) were not present, hence not utilized by humans for occupation or agriculture, until after $\sim 4000$ cal BP.

Humans are obviously capable of creatively adapting to even rapid changes in climate. Although climate does not unquestionably determine human life style, people living in already harsh environments (such as the Andean valleys) must constantly change life strategies (foraging, agricultural, hunting, etc.) to adjust to changes in basic living conditions. In such environments, changes in precipitation and discharge are the primary controls on the fluvial processes and landscape evolution; changes in precipitation and landscape are the ultimate controls on the availability of land for settlement, agriculture, and other human uses. This coupling of base level, paleoclimatic, and human occupation records in the Rio Ilave valley provides a more complete understanding of the natural forces that shaped landscape evolution and its anthropogenic modifications.

\section{Acknowledgements}

This work was supported, in part, by grants from the National Science Foundation (Grant Nos. ATM-9709035 and ESH-9975161 to C.A.R., ATM-9619672 and ATM-9809612 to P.A.B., BCS-9816313 and BCS-9978006 to M.S.A.). We thank the personnel of Instituto Nacional de Cultura for allowing us to work in the Ilave valley, the Autoridad Autonomo de Lago Titicaca for cooperating in our studies of the lake, and UNAVCO for providing differential GPS equipment and training. Albino Pilco Quispe, Virginia Incaconia, Makoto Suwa, and Niklas Bacher provided valuable field support.

\section{References}

Abbott, M., Binford, M.B., Brenner, M.W., Kelts, K.R., 1997. A $3500{ }^{14} \mathrm{C}$ yr high resolution record of lake level changes in Lake Titicaca, South America. Quat. Res. 47, 169-180.

Aceituno, P., 1996. Elementos del clima en el Altiplano Sudamericano. Rev. Geofis. 44, 37-55.

Aceituno, P., Montecinos, A., 1993. Circulation anomalies associated with dry and wet periods in the South American Altiplano. Fourth Int. Conf. South. Hemisph. Meteorol. Oceanogr., Am. Meteorol. Soc., pp. 330-331.

Aldenderfer, M., 1998a. Montane Foragers: Asana and the South-Central Andean Archaic. University of Iowa Press, Iowa City, IO.

Aldenderfer, M., 1998b. Proposal to the National Science Foundation. http://titicaca.ucsb.edu/chamak_pacha/docs/ nsf_proposal_1998/index.html). 
Aldenderfer, M., Klink, C., 1996. Archaic Period settlement in the Lake Titicaca basin: Results of a recent survey. Paper presented 36th Ann. Meet. Inst. Andean Stud., Berkeley, CA.

Aldenderfer, M., de la Vega, E., 1997. Informe preliminar: Excavaciones arqueologicas a tres sitios arcaicos de la cuenca del Rio Ilave, Sub-region de Puno, Region 'Jose Carlos Mariategui'. Rep. submitted to the Instituto Nacional de Cultura, Lima.

Allen, C.D., Breshears, D.D., 1998. Drought-induced shift of a forest-woodland ecotone: rapid landscape response to climate variation. Proc. Natl. Acad. Sci. USA 95, 1483914842 .

Baker, P., Rigsby, C., Seltzer, G., Fritz, S., Lowenstein, T., Bacher, N., Veliz, C., 2001a. Tropical climate changes at millennial and orbital timescales on the Bolivian Altiplano. Nature 409, 698-701.

Baker, P., Seltzer, G., Fritz, S., Dunbar, R., Grove, M., Tapia, P., Cross, S., Rowe, H., Broda, J., 2001b. The history of South American precipitation for the past 25,000 years. Science 291, 640-643.

Baucom, P.C., Rigsby, C.A., 1999. Climate and lake-level history of the northern Altiplano, Bolivia, as recorded in Holocene sediments of the Rio Desaguadero. J. Sediment. Res. 69, 597-611.

Berger, A., Loutre, P.J., 1991. Insolation values for the climate of the last 10 millions of years. Quat. Sci. Rev. 10, 297-317.

Binford, M., Kolata, A., Brenner, M., Janusek, J., Seddon, M., Abbott, M., Curtis, J., 1997. Climate variation and the rise and fall of an Andean civilization. Quat. Res. 47, 235-248.

Bond, G., Showers, W., Cheseby, M., Lotti, R., Almasi, P., deMenocal, P., Priore, P., Cullen, H., Hajdas, I., Bonani, G., 1997. A pervasive millennial-scale cycle in North Atlantic Holocene and Glacial climates. Science 278, 1257-1266.

Bond, G., Kromer, B., Beer, J., Muscheler, R., Evans, M.N., Showers, W., Hoffmann, S., Lotti-Bond, R., Hajdas, I., Bonani, G., 2001. Persistent solar influence on north Atlantic climate during the Holocene. Science 294, 2130-2136.

Boothroyd, J.C., Ashley, G.M., 1975. Processes, bar morphology, and sedimentary structures on braided outwash fans, northeastern Gulf of Alaska, In: Jopling, A.V., McDonald, B.C. (Eds.), Glaciofluvial and Glaciolacustrine Sedimentation. Can. Soc. Pet. Geol. Mem. 5, pp. 641-668.

Boserup, E., 1965. The Conditions of Agricultural Growth. Aldine, Chicago, 124 pp.

Brigdland, D.R., 2000. River terrace systems in north-west Europe: an archive of environmental change, uplift and early human occupation. Quat. Sci. Rev. 19, 1293-1303.

Bull, W.B., 1991. Geomorphic Response to Climatic Change. Oxford University Press, New York, 326 pp.

Cant, D.J., 1982. Fluvial facies models and their application. In: Scholle, P.A., Spearing, D. (Eds.), Sandstone Depositional Environments. Am. Assoc. Pet. Geol. Mem. 31, pp. 115-138.

Cant, D.J., Walker, R.G., 1978. Development of a braided fluvial model for the Devonian Battery Point Sandstone, Quebec. Can. J. Earth Sci. 13, 102-119.

Cross, S.L., Baker, P.A., Seltzer, G.O., Fritz, S.C., Dunbar, R.B., 2000. A new estimate of the Holocene lowstand level of Lake Titicaca and implications for tropical paleohydrology. Holocene 10, 21-32.

Cross, S.L., Baker, P.A., Seltzer, G.O., Fritz, S.C., Dunbar, R.B., 2001. Late Quaternary climate and hydrology of tropical South America inferred from an isotopic and chemical modeling of Lake Titicaca, Bolivia and Peru. Palaeogeogr. Quat. Res. 56, 1-9.

Darby, D.A., Whittecar, G.R., Barringer, R.A., Garrett, J.R., 1990. Alluvial lithofacies recognition in a humid-tropical setting. Sediment. Geol. 67, 161-174.

Davis, R.A., 1983. Depositional Systems: A Genetic Approach to Sedimentary Geology. Englewood Cliffs, New Jersey, Prentice-Hall Inc., 669 p.

DeMenocal, P., Ortiz, J., Guilderson, T., Sarnthein, M., 2000. Coherent high- and low-latitude climate variability during the Holocene Warm Period. Science 288, 2198-2202.

Erickson, C., 1999. Neo-environmental determinism and agrarian 'collapse' in Andean prehistory. Antiquity 73, 634-642.

Erickson, C., 2000. The Lake Titicaca basin: A Precolumbian built landscape. In: Lentz, D. (Ed.), Imperfect Balance: Landscape Transformations in the Precolumbian Americas. Columbia University Press, New York, pp. 311-356.

Erskin, W.D., Warner, R.F., 1988. Geomorphic effects of alternating flood and drought dominated regimes on NSW coastal rivers. In: Warner, R.F. (Ed.), Fluvial Geomorphology of Australia. Academic Press, pp. 223-239.

Garreaud, R., 1999. Multiscale analysis of the summertime precipitation over the Central Andes. Monthly Weather Review 127, 901-921.

Garreaud, R., Aceituno, P., 2001. Interannual rainfall variability over the South American Altiplano. J. Clim. 14, 2779 2789

Garreaud, R., Vuille, M., Clement, A., this issue. The climate of the Altiplano: observed current conditions and mechanisms of past changes. Palaeogeogr. Palaeoclimatol. Palaeoecol. S0031-0182(03)00269-4.

Jones, S.J., Frostick, L.E., Astin, T.R., 2001. Braided stream and flood plain architecture: the Rio Vero Formation, Spanish Pyrenees. Sediment. Geol. 139, 229-260.

Kaplan, A., Kushnir, Y., Cane, M., Blumenthal, M., 1997. Reduced space optimal analysis for historical datasets: 136 years of Atlantic sea surface temperatures. J. Geophys. Res. 102, 27835-27860.

Klink, C., in press. Archaic period research in the Rio Huenque Valley, Peru. In: Stanish, C., Aldenderfer, M., Cohen, A. (Eds.), Advances in the Archaeology of the Titicaca Basin. Cotsen Institute of Archaeology, University of California, Los Angeles, CA.

Klink, C., Aldenderfer, M., 1996. Archaic period settlement on the altiplano: Comparison of two recent surveys in the southwestern Lake Titicaca basin. Paper presented at the 
24th Annual Midwest Conference of Andean and Amazonian Archaeology, Beloit, WI.

Klink, C., Aldenderfer, M., in press. A projectile point chronology for the south-central Andean highlands. In: Stanish, C., Aldenderfer, M., Cohen, A. (Eds.), Advances in the Archaeology of the Titicaca Basin. Cotsen Institute of Archaeology, University of California, Los Angeles, CA.

Knox, J., 1972. Valley alluviation in southwestern Wisconsin. Ann. Assoc. Am. Geogr. 62, 401-410.

Kolata, A., Ortloff, C., 1996. Agroecological perspectives on the decline of the Tiwanaku state. In: Kolata, A. (Ed.), Tiwanaku and its Hinterland: Archaeology and Paleoecology of an Andean Civilization, 1: Agroecology. Smithsonian Institution Press, Washington, DC, pp. 181-201.

Lenters, J., Cook, K., 1997. On the origin of the Bolivian high and related circulation features of the South American climate. J. Atmos. Sci. 54, 656-677.

Lenters, J., Cook, K., 1999. Summertime precipitation variability over South America: role of the large-scale circulation. Mon. Weather Rev. 127, 409-431.

Melice, J., Roucou, P., 1998. Decadal time scale variability recorded in the Quelccaya summit ice core $\delta^{18} \mathrm{O}$ isotopic ratio series and its relation with the sea surface temperature. Clim. Dyn. 14, 117-132.

Miall, A.D., 1978. Lithofacies types and vertical profile models in braided river deposition: A summary, in Miall, A.D., Fluvial Sedimentology: Canadian Society of Petroleum Geologists, Memoir 5, 597-604.

Miall, A.D., 1982. Analysis of Fluvial Depositional Systems. Am. Assoc. Pet. Geol., Tulsa, OK, 75 pp.

Miall, A.D., 1996. The Geology of Fluvial Deposits: Sedimentary Facies, Basin Analysis and Petroleum Geology. Springer, New York, 598 pp.

Nanson, G.C., East, T., Roberts, R.G., 1993. Quaternary stratigraphy, geochronology and evolution of the Magela Creek catchment in the monsoon tropics of northern Australia. Sediment. Geol. 83, 277-302.

Nobre, P., Shukla, J., 1996. Variations of sea surface temperature, wind stress, and rainfall over the tropical Atlantic and South America. J. Clim. 9, 2464-2479.

Orlove, B., Chiang, J., Cane, M., 2000. Forecasting Andean rainfall and crop yield from the influence of El Nino on Pleiades visibility. Nature 403, 68-71.

Ortloff, C.R., Kolata, A.L., 1993. Climate and collapse: agroecological perspectives on the decline of the Tiwanaku state. J. Archaeol. Sci. 20, 195-221.

Paduano, G., Bush, M., Baker, P., Fritz, S., Seltzer, G., this issue. A vegetation and fire history since the Last Glacial Maximum of Lake Titicaca. Palaeogeogr. Palaeoclimatol. Palaeoecol. S0031-0182(03)00281-5.

Porter, S.C., An, Z., Zheng, H., 1992. Cyclic Quaternary alluviation and terracing in a nonglacial drainage basin on the northern flank of the Qinling Shan, China. Quat. Res. 38, 157-169.

Reading, H.G., 1996. Sedimentary Environments: Process, Products, and Stratigraphy. Blackwell, Oxford, 688 pp.
Reineck, H.E., Singh, I.B., 1980. Depositional Sedimentary Environments. Springer, New York, 549 pp.

Reneau, S.L., 2000. Stream incision and terrace development in Frijoles Canyon, Bandolier National Monument, New Mexico and the influence of lithology and climate. Geomorphology 32, 171-193.

Rollins, S.M., 2001. Quaternary Lacustrine and Fluvial History of the Central Bolivian Altiplano as Recorded in Subsurface Strata of the Rio Desaguadero Valley, Bolivia. M.Sci. Thesis, East Carolina University, Greenville, NC, 152 pp.

Rollins, S.M., Rigsby, C.A., Warren, M.R., Bradbury, J.P., 2000. Quaternary lacustrine and fluvial history of the central Bolivian Altiplano as recorded in subsurface strata of the Rio Desaguadero, Bolivia. GSA Abstracts with Programs $32,7$.

Rose, J., Turner, C., Coope, G.R., Bryan, M.D., 1980. Channel change in a lowland river catchment over the last 13,000 years. In: Cullingford, R.A., Davidson, D.A., Lewin, J. (Eds.), Timescales in Geomorphology, pp. 159-175.

Rose, J., Boardman, J., 1983. River activity in relation to short-term climatic deterioration. Quat. Stud. Pol. 4, 189198.

Rust, B.R., 1978. Depositional models for braided alluvium. In: Miall, A.D. (Ed.), Fluvial Sedimentology. Can. Soc. Pet. Geol. Mem. 5, pp. 605-625.

Schumm, S.A., 1993. River response to baselevel change: implications for sequence stratigraphy. J. Geol. 101, 279-294.

Seltzer, G.O., Cross, S., Baker, P., Dunbar, R., Fritz, S., 1998. High-resolution seismic reflection profiles from Lake Titicaca, Peru/Bolivia. Evidence for Holocene aridity in the tropical Andes. Geology 26, 167-170.

Seltzer, G., Rodbell, D., Baker, P., Tapia, P., Fritz, S., Rowe, H., Dunbar, R., 2002. Asynchronous warming of the tropics at the last glacial-interglacial transition. Science 296, 16851686.

Shelton, J.W., Noble, R.L., 1974. Depositional features of a braided-meandering stream. Am. Assoc. Pet. Geol. Bull. 58, $742-754$.

Smith, N.D., 1974. Sedimentology and bar formation in the upper Kicking Horse River, a braided outwash stream. J. Geol. 82, 3407-3420.

Smith, N.D., Smith, D.G., 1984. William River: An excellent example of channel widening and braiding caused by bedload addition. Geology 12, 78-82.

Stanish, C., 2003. Ancient Collasuyo. University of Iowa Press, Iowa City, IA.

Stanish, C., de la Vega, E., Steadman, L., Chavez, C., Frye, K., Onofre Mamani, L., Seddon, M., Calisaya, P., 1997. Archaeological survey in the Juli-Desaguadero region of Lake Titicaca basin, southern Peru. Fieldiana Anthrop. 29. Field Museum of Natural History, Chicago.

Steadman, L., 1995. Excavations at Camata: An Early Ceramic Chronology for the Western Titicaca Basin, Peru. Ph.D. Thesis, University of California, Los Angeles, CA, $682 \mathrm{pp}$

Stuvier, M., Braziunas, T.F., 1993. Sun, ocean, climate and 
atmospheric ${ }^{14} \mathrm{CO}_{2}$ : an evaluation of causal and spectral relationships. Holocene 3, 289-305.

Stuiver, M., Reimer, P.J., Bard, E., Beck, J.W., Burr, G.S., Hughen, K.A., Kromer, B., McCormac, F.G., van der Plicht, J., Spurk, M., 1998a. INTCAL98 radiocarbon age calibration, 24,000-0 cal BP. Radiocarbon 40, 1041-1083.

Stuiver, M., Reimer, P.J., Braziunas, T.F., 1998b. High-precision radiocarbon age calibration for terrestrial and marine samples. Radiocarbon 40, 1127-1151.

Sugai, T., 1993. River terrace development by concurrent fluvial processes and climate change. Geomorphology 6, 243252.

Thompson, L.G., Mosley-Thompson, E., Daansbarg, W., Grootes, P., 1986. The 'Little Ice Age' as recorded in the stratigraphy of the tropical Quelccaya ice cap. Science 234, 361-364.
Thompson, L.G., Davis, M.E., Mosley-Thompson, E., Sowers, T., Henderson, K.A., Zagorodnov, V.S., Lin, P.-N., Mikhalenko, V.N., Campen, R.K., Bolzan, J.F., Cole-Dai, J., Francou, B., 1998. A 25,000-year tropical climate history from Bolivian ice cores. Science 282, 1858-1864.

Vandenberghe, J., 1995. Timescales, climate and river development. Quat. Sci. Rev. 14, 631-638.

Vuille, M., Bradley, R., Keimig, F., 2000. Interannual climate variability in the Central Andes and its relation to tropical Pacific and Atlantic forcing. J. Geophys. Res. 105, 1244712460.

Zhou, J., Lau, K.-M., 1998. Does a monsoon climate exist over South America? J. Clim. 11, 1020-1040. 